\title{
Chapter 1 \\ Getting the Short End of the Stick: Power Relations and Their Distributive Outcomes for Lower-Income Countries in Transfer Pricing Governance
}

\author{
Cassandra Vet, Danny Cassimon, and Anne Van de Vijver
}

\subsection{Introduction}

Within the shadow of the G20-OECD Base Erosion and Profit Shifting (BEPS) Project, transfer pricing experts pack up their suitcases to go and assist developing countries in their efforts to implement a complex regime of transfer pricing auditing (Peters 2015; Tax Inspectors Without Borders 2018). At first glance, these efforts support the reduction of fiscal losses caused by "aggressive" transfer pricing practices, an important channel of corporate tax avoidance in Sub-Saharan Africa (Fuest and Riedel 2012). Yet, while these efforts strengthen the audit capacity of developing countries, the rules that guide these capacity development projects reinforce the distributional imbalance of the international tax regime (Magelhaes 2018). This chapter sheds light on the power relations at play during the G20-OECD reform of transfer pricing guidelines to highlight how these relations shape the distributional outcomes of the international tax regime.

Mosquera Valderrama $(2015,2018)$ already argued that the reform should not only offer a way out of the collective action problem developing countries face in the regulation of transfer pricing but also bring about solutions that are efficient and implementable within the tax culture and context of these countries. From this view, the legitimacy of the BEPS project depends on more than the sole representation of

C. Vet $(\bowtie) \cdot$ D. Cassimon

Institute of Development Policy and Antwerp Tax Academy, University of Antwerp, Antwerp,

Belgium

e-mail: Cassandra.vet@uantwerpen.be; danny.cassimon@uantwerpen.be

A. Van de Vijver

Faculty of Law and Antwerp Tax Academy, University of Antwerp, Antwerp, Belgium

e-mail: anne.vandevijver@uantwerpen.be 
lower-income countries throughout the reform process. If the BEPS project strives for developing country legitimacy, then both input and output legitimacy should be guaranteed. Here, in light of the embedded imbalance between source and resident jurisdictions in the tax regime (Magelhaes 2018; Christians 2017), we introduce an additional yardstick to evaluate the output legitimacy of the BEPS project, namely, distributive justice.

Moreover input and output legitimacy are not independent; the distribution and relations of power active during the BEPS reform shape the outcomes. Global institutional answers to corporate tax avoidance cannot be detached from their internal power distribution. Hearson (2018a), for instance, stressed that the multilateral institutional answers supported by most tax governance scholars will in all likelihood hold perverse effects for developing countries. History taught that the institutionalized outcomes of negotiations produced within a context of imbalanced power relations reflect this imbalance, a point Hearson (2018b) demonstrated through his empirical analysis of the distributional bias in Double Tax Treaties (DTT). Importantly tough, when we try to grasp power in global tax governance, we have to move beyond a one-dimensional view on power and its limited focus on the observable decision-making struggles that take place during political participation (Lukes 2005). To illustrate, even the institutions of the global tax regime tend to stabilize the regime's adherence to neo-liberalism (Lesage and Vermeiren 2011), an ideological base that preserves the unequal distribution of taxing rights as we will discuss later. In all, the historical underrepresentation of developing countries within the international tax regime is not simply readdressed by merely giving those previously marginalized a seat at the table.

This chapter maps out the power relations that molded the reform of the transactional profit split method (TPSM), one of the transfer pricing methods put forward in the OECD transfer pricing guidelines, to its specific distributional outcomes. As transfer pricing literally divides the profits of international corporate wealth into national tax baskets by pricing cross-border interactions, we use the material interests of developing countries in transfer pricing governance as our heuristic device to guide us through the multiple power relations. To start, we approach the privatepublic tug-of-war over authority in profit allocation as the struggle over the "size of the cake". Clearly, transnational corporations (TNCs) have an interest in maintaining their discretion in profit allocation maintain their leeway to engage in aggressive tax planning keep some of "calculated ambiguity" in their tax planning structures alive (Sharman 2010). Secondly, whereas each state has the fiscal objective to enlarge its tax base, the struggle over the slice of the cake represents the interstate struggle to bring the biggest share of TNCs' profits in the national tax base (Lips 2019). Finally, the third element touches upon Mosquera Valderrama's (2015, 2018) original discussion of the output legitimacy of the BEPS Project. Besides dealing with developing countries' stakes in having a bigger cake to share or getting a decent slice of the cake, the regime should also be efficient and implementable within the tax culture and context of these countries. Or rather, lower-income countries should also be able to actually eat their slice of the cake. The institutionalization of transfer pricing guidelines, and in this case specifically the revised guidance of the TPSM, 
reveals that even though the reform expanded the size of the overall cake of taxable profits, the criteria that authorize the use of the TPSM, along with the ongoing complexity of the regime, make it difficult for lower-income countries to obtain a decent slice of the cake and actually eat it.

Now, the question remains: "What are the power relations that produce these outcomes?" For this reason, we start off with a conceptual discussion on power in global tax governance. Afterward, a short discussion on the profit split method illustrates the appeal of the TPSM case study as it deals with the contentious issue of synergy or residual profits. In turn, we shed some light on the standard-setting process, highlight the key stakeholders involved, and elaborate on the collected data used for the qualitative content analysis. Afterward, we dive into the technicized discourse of the standard-setting process with our power goggles at hand to flesh out the distributional conflicts and power relations at play. Here, the analysis is organized along the three previously discussed developmental interests: the size of the cake, the slice, and whether or not these countries are actually able to eat their cake. In the end, we discuss our observations in light of the recent efforts to integrate lower-income countries and critique the pluralist expectation that proper representation of developing countries is a sufficient measure to make sure that the regime is also legitimate in the South.

\subsection{The Different Faces of Power in Global Tax Governance}

Foucault once said that "the conception of society that predominates is a hangover from an earlier social formation" (Kelly 2009, p. 43). This comment on the contingency of social order spells out the relation between the colonial context that gave rise to the international tax regime and the enduring bias of the regime to resident countries (Magelhaes 2018). From this angle, the bias of the regime toward resident taxation, the countries where the headquarters are located, and against source taxation, where the activities are taking place, is hardly surprising but nonetheless harmful. Yet, the distributional justice of the BEPS project in general, and specifically in transfer pricing, only recently gathered wider interest in academic circles (Magelhaes 2018; Christians 2017; Hearson 2018a; Christensen and Hearson 2019) and is rarely explicitly addressed within the reform agenda despite the distributive conflict over the allocation of profits between states (Lips 2019). This conflict would hardly come to light when one would solely focus on the observable expressions of interest and conflict during the initial BEPS policy process.

However, both Foucault and Lukes (2005, p. 90) drew attention to less visible displays of power and highlighted how power relations can be at their strongest when their workings remain hidden. The unpoliticization of the distributional impact, for instance, the technically insulated discourse of international tax experts, gave the distributive decisions an unpolitical aura, while these decisions did mold the regime further toward the interests of transnational corporations (Picciotto 2018a; Buttner and Thiemann 2017). Lukes (2005) described these exercises of power as 
power in the third dimension, power that secures consent without the presence of struggles and produces its results through the invisible constraints we put upon ourselves. To illustrate, the technical and expertise-led nature of the discourses during tax meeting insulated the standard-setting discussions from "political wrangling," a constraint that the stakeholders put on themselves.

Admittedly, some struggles did take place out in the open; Lukes (2005) refers to these power struggles as exercises of power in the first dimension. When policy advisors and tax advisors reframed civil society's claim for transparency into the policy goal to improve risk assessment capacity, the discursive struggle was visible (Christensen 2020). Still, while civil society did manage to get the topic on the agenda, their claim for transparency lost some of its scope as it fell outside of the ideational consensus on the limits of appropriate solutions. In other words, or in more Foucauldian terms, the claim for transparency as brought by civil society activists did not fit within "the regime of truths" upheld within the transnational tax sphere. These "truths" determine what may be held true in a particular discourse" and signal how different discourses relate to reality (Kelly 2009, p. 109). Basically, the demand for transparency challenged how the transnational tax discourse framed appropriate tax behavior of TNCs and governments. As a result, the professionals involved transformed the original demand into the need to improve risk assessment capacity while they made sense of the need for transparency (Christensen 2020), a goal that did fit within their view on reality. So, whereas Lukes (2005) tried to pull apart different forms or capacities of "having power," power is exercised within human and societal relations, and these power relations have manifold and overlapping characters.

Another display of power, power in the second dimension (Lukes 2005), is the use of power to shield the policy agenda from certain discussions and bring others to the fore of the debate. Indeed, it is important to reflect on not only what is discussed but also what is not and why. The refusal of the G20-OECD members to take up the demand of developing countries, their demand to reassess the allocation of taxing rights between source and resident countries, initially kept the topic out of the list of issues that needed to be resolved (Burgers and Mosquera Valderrama 2017, p. 31). That said, the mobilization of this bias in agenda setting clearly highlights how these forms of power shape the distributional outcomes of the project, but the counterpower within this relation strengthened and the topic now penetrates actions taken in light of the digitalized economy (Grondona 2019; Christensen and Hearson 2019).

As mentioned, both authors marked less visible forms of power relations and indicated that compliance not necessarily means a vacuum of power struggles. On the contrary, Foucault argues that power is not some kind of possession of people but rather always present in the relations that structure our social order (Kelly 2009, p. 37). Also, power tends to hide itself but can be found in its products, the social relations itself. According to Foucault power even has a strategic nature, a tendency to preserve itself and the relations it produced, that goes beyond intent of the agents involved (Kelly 2014, pp. 70-71). Though power cannot exist without people, the strategic nature and its organizing effect can be seen as a net effect of all the 
intentional exercises of power within the network of relations (Kelly 2009, p. 47). Lesage and Vermeiren (2011), for instance, discussed how the institutional pillar of neoliberal globalization provides resilience to neoliberal globalization even when ideational support for the free movement of goods and capital is in decline. In a way, the net effects of power relations in global tax governance gave rise to an institutional setting wherein "the material interests at the core of neo-liberal hegemony" are preserved through its horizontal governance setting amidst the collective action problems in international taxation (Lesage and Vermeiren 2011, p. 54).

Where Lukes (2005) drew attention to how power also has its effects when it puts constraints on ourselves and our rationality, Foucault sheds light on the power relations that produce these kinds of constraints or rationality (Kelly 2014). Here, his emphasis on discourses, the dialectical relation between knowledge and power and "regimes of truths", clarifies the strength of expertise networks and the problem of complexity in transfer pricing governance (Kelly 2014). The discourses of the experts and policymakers put forward in policy discussions on transfer pricing policy share a narrow and technical view on the meaning of transfer pricing and its relation to reality and the world economy. However, while the "regimes of truths" within this discourse were rarely challenged as the centrality of expert-led knowledge shielded the discourses from other "truths," policy-makers sought solutions to regulatory challenges within these narrow discourses and perspectives on reality. As a result, the complexity of the regime grew in response to the inability of policymakers to come up with solutions outside of this technocratic consensus (Buttner and Thiemann 2017). Thereby the regime not only opened the door for tax advisors to capitalize on the indeterminacy created but also maintained the centrality of expert knowledge (Picciotto 2015; Sikka and Hampton 2005; Sharman 2010). These tax advisors grew so powerful within transfer pricing policy that Picciotto (2018a) even pointed out how these players shaped the regime in favor of private authority through regulatory arbitrage.

To some extent, this focus on less visible expressions of power might feel deterministic, undermining the agency of developing countries to turn the table around, or resist against the contingent distribution of taxing rights. Yet, Foucault underpins that power is always connected to resistance, or counterpower, as there would be no need for a power relation without the possibility of resistance (Kelly 2009, pp. 107-108). The networks of power in transfer pricing are emergent and would seize to exist without the regular production of those involved (Kelly 2009, p. 47). Consequently, these power relations also coincide with micro-resistances that can produce macro-resistances as the social order is always fluid and never fully stable. To illustrate, the regulatory fixes that added to the complexity of the regime are in part ways to stabilize the transfer pricing regime, its "regime of truths", and its associated social order within a shifting context. Nonetheless, these fixes also planted the seeds for the decay of this regime as the growing complexity and uncertainty of the transfer pricing rules undermined the authority of expert networks (Buttner and Thiemann 2017). The transfer pricing rules are now slowly politicizing (Grinberg 2016), and the distribution of taxing rights grew to be one of the contentious issues in the reform on the digitalized economy due to the mobilization of 
lower-income countries. In other words, the social order upheld in the international tax regime is shifting (Christensen and Hearson 2019).

\subsection{The Profit Split Method and the OECD Standard-Setting Process}

As said, the material interests of lower-income countries in transfer pricing governance are our heuristic device to analyze the power relations and their distributive outcomes of the TPSM. Important to know, the distributive conflict in transfer pricing materializes in the contentious nature of price requalifications by national revenue authorities. Where the current global tax regime still rests upon the separation of the TNC's tax base in different tax jurisdictions, transfer pricing or intracompany pricing is the everyday pricing technique to do so. However, the dominant principle governing this price-setting practice, the arm's length principle (ALP), is conceptually and practically flawed. This principle prescribes that unrelated party or rather market prices are the benchmark for related party transactions even though the nature of these transactions is different and reliable comparable transactions are difficult to come by (Picciotto 1992). Nevertheless, the authoritative standards of the OECD transfer pricing guidelines put forward methods to calculate the pricing range on the basis of these "comparable uncontrolled transactions" (CUP). The OECD guidelines started out as a manual for transfer pricing for TNCs; however, the distributional value of these guidelines lies in their use for the requalification of reported profits by revenue authorities. As many countries integrated these soft law standards (Grinberg 2016), these guidelines are the basis for profit requalification through transfer pricing auditing. Thereby, the content of these guidelines regulates when and how much tax authorities can adjust the division of profits by TNCs.

Importantly tough, the transactional profit split method (TPSM) changes the rules of the game set out above since it draws in residual profits. The profit split method is different from the CUP-based methods as it divides the combined profits earned from a transaction or transactions according to one or more "allocation keys" (Picciotto 2018b, p. 17). Therefore, the revision of the TPSM guidance brings in another layer in the distributive conflict, the struggle over residual profits. When the tax base is purely based on CUP-based transfer pricing methods, these profits often remain unregulated and vulnerable for aggressive tax planning (Cobham et al. 2019). On top of that, TNCs also have the tendency to locate their residual profits, besides in tax haven jurisdictions, in the jurisdictions where its top holdings are located (de Graaf et al. 2014, p. 309; Grondona 2019). The role of the TPSM guidance is to clarify when the method is most appropriate in comparison with the other methods. In other words, the revision of the guidance matters for countries as well as TNCs as it indicates the circumstances wherein revenue authorities can requalify the reported profits when they did not account for a part of the residual profits. 
In addition to these distributional consequences, the reform of the TPSM opened the door to address the uncertain and costly implementation of the transfer pricing auditing in developing countries (Mehta and Siu 2016). The G20-OECD regime departs from a case-by-case logic, suggesting an in-depth investigation of the transaction or the "accurate delineation of the transaction," before comparing the relative suitability of different transfer pricing methods (Kadet et al. 2018). As a result, the BEPS Monitoring Group ${ }^{1}$ and its affiliated scholars argue for the simplification and standardization of the transfer pricing regime so that developing countries are able to protect their corporate tax base (BEPS Monitoring Group 2018; Mehta and Siu 2016; Picciotto 2018b; Waris 2017). In fact, Mehta and Siu (2016) recommended lower-income countries to extend their use of profit split methods to protect their tax base through simplification and to avoid out of balance administration costs. However, the TPSM only brings incremental change to the current framework since it solely divides the profits of a certain group of transactions into different jurisdictions and not the global tax base of a TNC. Nonetheless, the method potentially simplifies the distribution of the tax base and could thereby help developing countries to actually perform the requalifications needed to protect its tax base (Greil 2017; Mehta and Siu 2016). This way, lower-income countries not only obtain their slice of the cake but are also able to eat it.

At the moment, the BEPS Monitoring Group (2018) describes the outcome of the revised guidance as the "lowest common denominator." Therefore, the Group continues their plea for simplification at the UN level and argues for standardized allocation, specific industry weights, objective measures, and industry-wide APAs (BEPS Monitoring Group 2018; Kadet et al. 2018). Meanwhile, the work on the revised nexus and profit allocation rules has been picked up by Action 1 (Tax challenges arising from digitalization). Since the Action 1 Report found that the whole economy was digitalizing (OECD 2015), this working program has a very wide scope. The ambition is to deliver a long-term and consensus-based solution in 2020 that reflects the right balance between precision and administrability for jurisdictions at different levels of development (OECD 2019).

Besides its clear distributional implications, the reform of the TPSM guidance has other advantages as a case study on developmental interests and power relations in global tax governance. Whereas the four BEPS minimum standards find their way to developing countries through the Inclusive Framework, Actions 8-10 on transfer pricing deserve our interest as a result of the strength and the implementation rate of the OECD transfer pricing rules (Grinberg 2016).

\footnotetext{
${ }^{1}$ The BEPS Monitoring Group (BMG) is a global network of independent researchers on international taxation, sponsored by tax justice organizations, concerned with the effects of tax avoidance by transnational corporations, especially on development. Its aim is to produce reports commenting on proposals for the reform of the international system for the taxation of transnational corporations.
} 
Initially, the BEPS Working Parties failed to reach a consensus on the TPSM guidance, and therefore the guidance became part of the agenda for ongoing work published in the 2015 Final Report (Grinberg 2016, p. 1161). This not only indicates the contentious, and therefore politically interesting, nature of this guidance; it also gave rise to the involvement of developing countries. To clarify, the Inclusive Framework notes that all members are invited to participate on equal footing in the ongoing work on transfer pricing that followed the 2015 Final Report (OECD 2017a). Therefore, this chapter discusses how the power relations found in the micro-level interactions within the policy-making environment shaped the distributional outcomes for developing countries, starting from the 2015 agenda for ongoing work until the 2018 published Revised Guidance on the Application of the TPSM.

Throughout the reform process, the G20-OECD worked with public discussion drafts and publicly recorded stakeholder discussions to gather feedback for Working Party 6 (WP6). This working party is the G20-OECD working group in charge of the policy reform process that consisted of state representatives and OECD experts. Thus, this group prepared, along with the OECD secretariat, the different discussion drafts (see dark grey boxes Fig. 1.1) and processed the written and oral feedback given during the public stakeholder consultation sessions (see light grey boxes Fig. 1.1). The process depicted in Fig. 1.1 thereby depicts the process wherein new pieces of discourse, draft documents, working party meetings, or stakeholder discussions feed into the subsequent ones. The data for this analysis exists out of the recordings of the different stakeholder consultation sessions, the discussion drafts, and the final revised guidance. Unfortunately, the insights on the positions of the state representatives are solely based on their interventions during the stakeholder meetings and the content of the policy documents. As a result, we based our analysis on a qualitative content analysis of the different policy papers ${ }^{2}$ on the TPSM guidance and the recorded stakeholder discussions while paying specific attentions to the interaction between the different pieces of discourse. In addition, we also calculated the speaking time divided over the different participants to highlight who is most vocal during the stakeholder meetings and has or feels authorized to speak (Figs. 1.1, 1.2, 1.3, 1.4, and 1.5).

Despite the lack of data on the WP6 discussion, we were able to illustrate (see Fig. 1.2) the number of interventions made by state representatives during the stakeholder meetings as these are part of the recorded sessions. Here it is clear that the USA together with Japan were most active during the stakeholder discussions.

One of the common critiques on the legitimacy of the BEPS project is the lack of integration of lower-income countries in the agenda- and standard-setting process (Mosquera Valderrama et al. 2018). However, stakeholder involvement is also

\footnotetext{
${ }^{2} 2015$ Final Report action 8-10 section on the transactional profit split, the Public Discussion Draft Revised Guidance on Profit Splits 4 July 2016, the Public Discussion Draft Revised Guidance on Profit Splits 22 June 2017, The Revised Guidance on the application of the transactional profit split June 2018
} 
1 Getting the Short End of the Stick: Power Relations and Their Distributive...
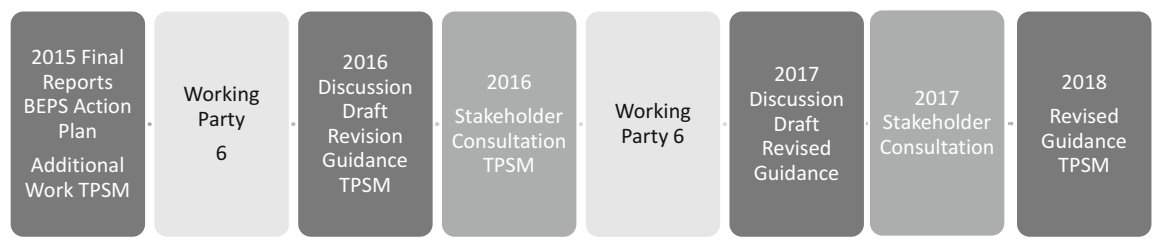

Fig. 1.1 Institutionalization of the TPSM guidance

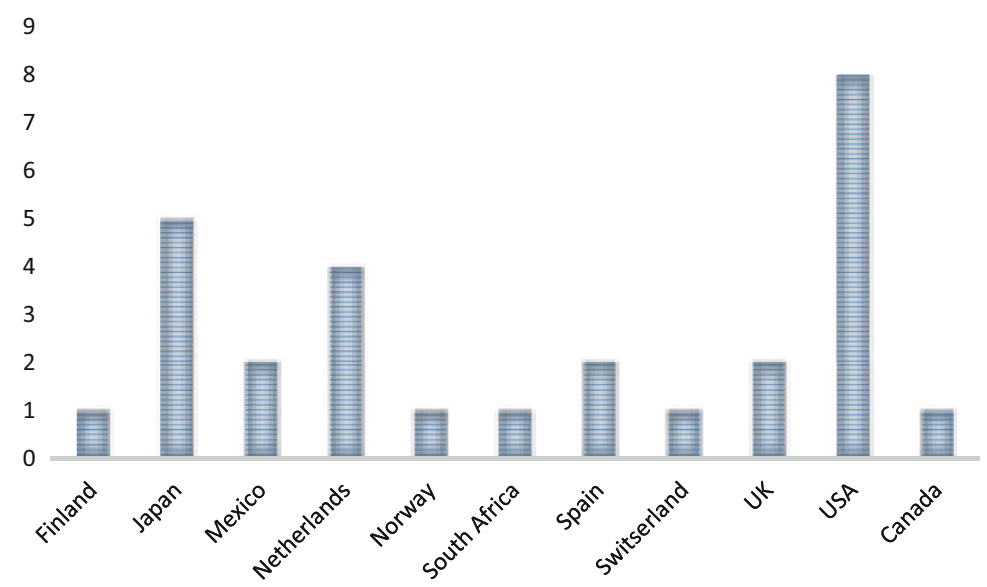

Fig. 1.2 Number of interventions from WP6 members during the stakeholder discussions (WP6 2016a, b, 2017a, b)

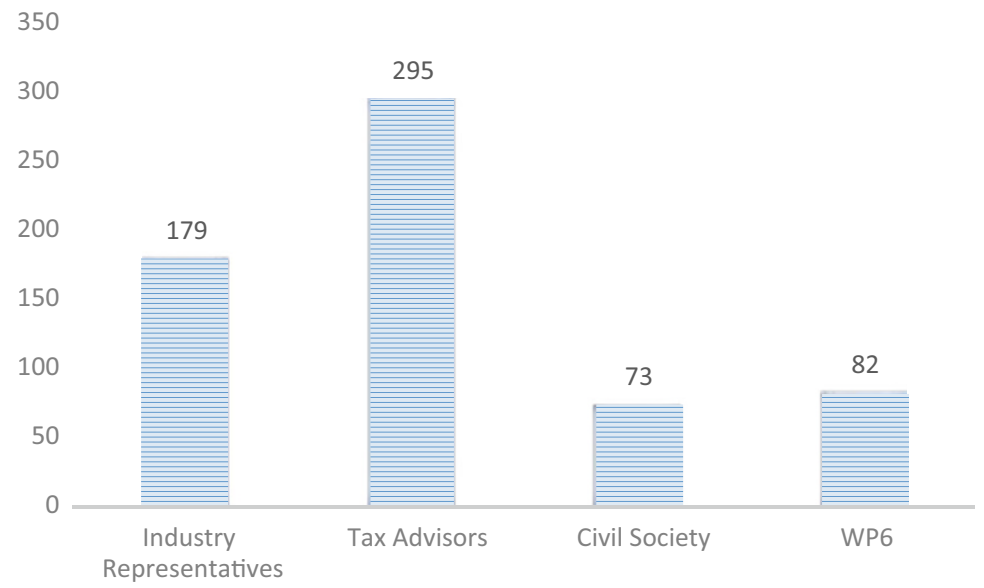

Fig. 1.3 Speaking time during stakeholder discussions (number of minutes) (WP6 2016a, b, 2017a, b) 


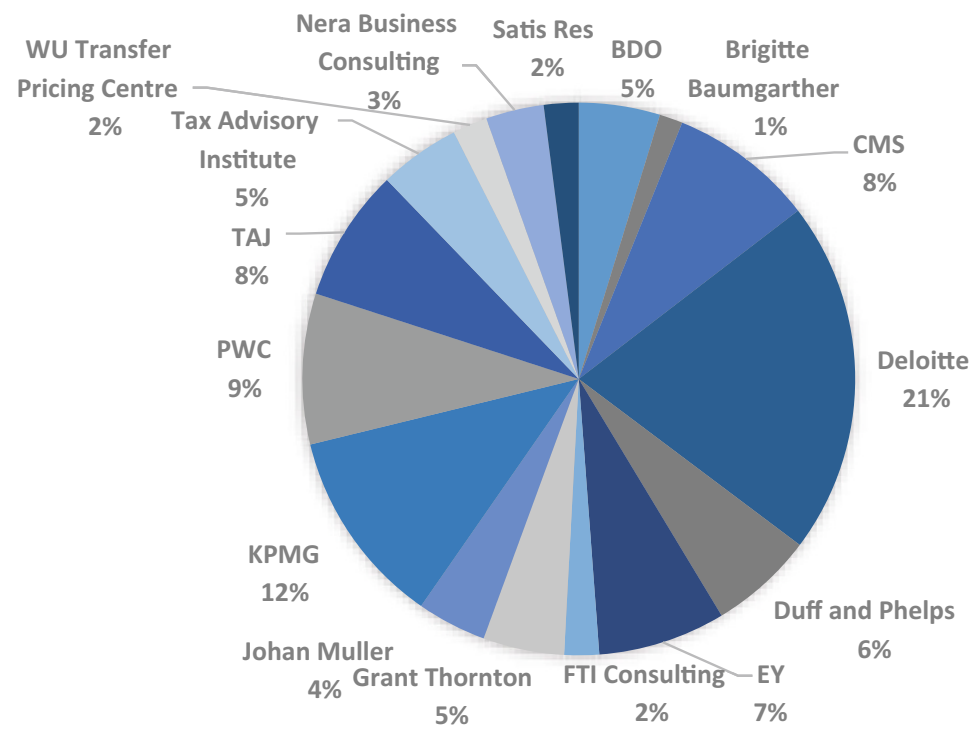

Fig. 1.4 Distribution of speaking time within tax advisory industry (WP6 2016a, b, 2017a, b)

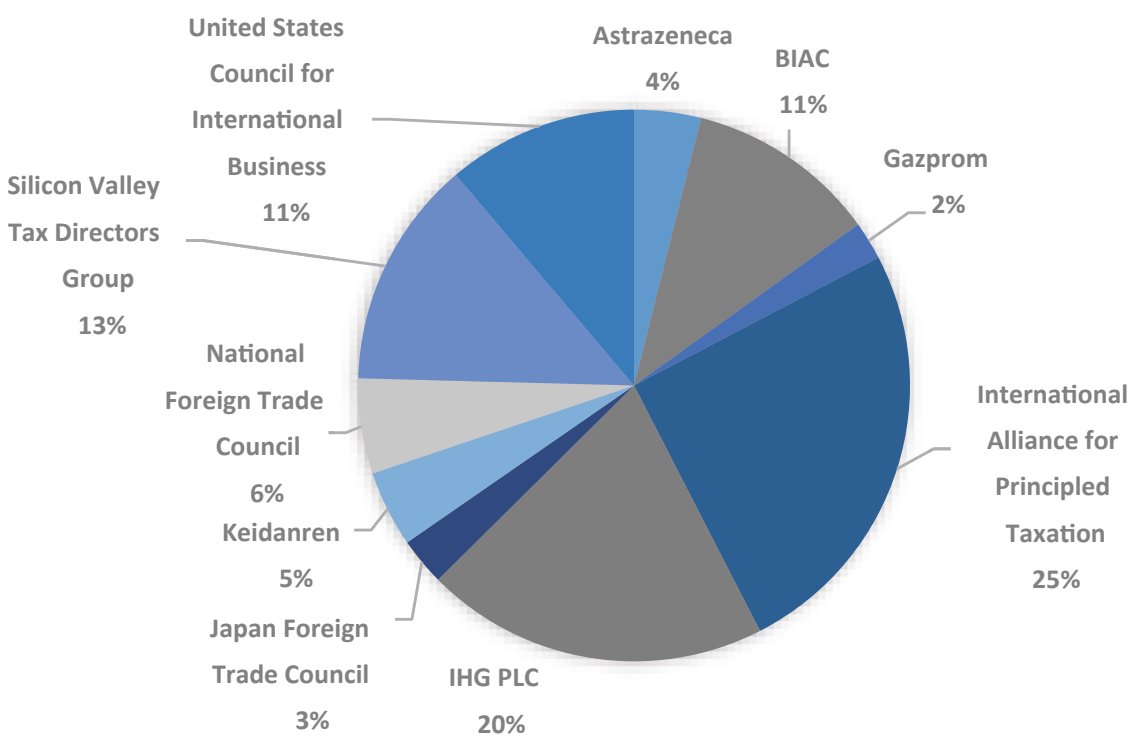

Fig. 1.5 Distribution of speaking time of business representatives (WP6 2016a, b, 2017a, b)

unevenly divided among the different groups of stakeholders as is shown by the distribution of speaking minutes over the different groups during the public discussions (see Fig. 1.3). An observation that supports the argument explained above on the role of expert knowledge and how experts have the authority to decide on what is 
important in terms of transfer pricing policy. Although the BEPS Monitoring Group, part of civil society (see Fig. 1.3), was the most active participant in terms of spoken minutes (70 min), this group is, besides the University of Lausanne (part civil society Fig. 1.3), the only non-business representative that took part of the stakeholder discussions. A second important observation on authority in standard-setting is the dominant presence of the tax advisory industry (see Fig. 1.3).

When taking a closer look at the internal allocation of minutes within the tax advisory sector, it becomes evident that the Big Four companies mostly took the floor, along with Taj, a specialized Deloitte network entity in international tax, and CMS, an international tax law firm (see Fig. 1.4). Deloitte is further the clear frontrunner in terms of minutes spoken, especially when we add up Taj's speaking time as TAJ is actually Deloitte network entity. From this view Deloitte's discourse took up about $30 \%$ of the debate (see Fig. 1.4).

A second hint on the uneven power relations in standard-setting is the distribution of time among the business representatives. Firstly, within this group the International Alliance for Principled Taxation (IAPT) leads the discussions while representing a group of multinationals in search of predictable tax rules and the end of double taxation. Although the group clearly represents business interests, it is the Baker McKenzie law firm, a firm active in the tax advisory industry, that pleads in the name of this group. On a regional level, business councils of the USA and Japan follow a similar high level of engagement as their state representatives. Finally, BIAC is the overall representatives for business interests at the OECD, and in sectoral terms we observe the presence of the pharmacy industry (AstraZeneca), the hotel industry (IHG PLC), and a Russian gas exporter (Gazprom). Overall, the presence of business from lower-income countries is lacking, but the same can be said on the representation of small- and medium-sized businesses.

\subsection{The Cake}

Similar to the academic debate, as shown again from our analysis of the debates, the stakeholders spend a great deal of their time and energy scrutinizing the ALP principle during the public TPSM discussions. However, in contrast to the negative viewpoint on the ALP often shared by acadamics, most representatives defended and expanded the role of the ALP in transfer pricing. To illustrate, tax advisors from TAJ and a representative from BIAC argued for the limited use of the TPSM as unrelated parties only use a profit split method in extremely rare circumstances (WP6 2016a, b). This way, they discursively expanded the interpretation of the ALP by arguing that the ALP is not just a benchmark for price setting but also a benchmark for selecting the appropriate transfer pricing method. In all, the majority of tax advisors and business representatives struggled with the revised guidance on the TPSM as they felt that it expands the application of the method beyond "arm's length circumstances" (WP6 2016a). 
To some degree, this observation is correct as the TPSM guidelines challenge the application of the ALP in transfer pricing matters. First of all, the G20-OECD wrote in 2015 that "the main strength of the method is that it can provide solutions for highly integrated operations for which a one-sided method would not be appropriate" (OECD/G20 2015, p. 57). A one-sided method essentially comes down to a method whereby you price the transaction of the local affiliate and a related party with the help of a CUP. These CUPs or comparables are the cornerstone for the implementation of the ALP in transfer pricing, and by acknowledging that these can be inappropriate, WP6 opened the door to the wider ALP debate. Two years later, WP6 continues this train of thought and recognized that certain related party transactions have "specific, possibly unique, facts and circumstances of the associated enterprises that are not present in independent enterprises" (OECD 2017b, p. 5). Further, WP6 bridges the ideational controversy by taking on a language of "arm's length outcomes." And in the end, the final guidance defensively excludes the private sector's interpretation by stating that "It is sometimes argued that a transactional profit split method is rarely used among independent enterprises, and thus its application in controlled transactions should be similarly rare. However where such a method is determined to be the most appropriate, this should not be a factor since transfer pricing methods are not necessarily intended to replicate arm's length behavior, but rather to serve as a means of establishing and/or verifying arm's length outcomes for controlled transactions" (OECD 2017b, p. 5, 2018, p. 13).

Now, what are the interests at stake in this tug-of-war on the role of the ALP in the revised TPSM guidance? Basically, the private and public sector both struggle for control over residual profits, the profits beyond arm's length that TNCs create through their decision to integrate activities in their value chain. One-sided or CUP-based methods do not account for profits beyond arm's length. In the case that an affiliate prices all related party transactions on the basis of one-sided methods, then, all residual profits fall outside of that affiliate's tax base (Cobham et al. 2019). Therefore, the TPSM lends its attractiveness for public authorities from its two-sided character wherein the full profits related to the transaction are part of the profits to be split among the associated jurisdictions.

This clarifies the business representatives' concern on the "subjective application" of the TPSM by revenue authorities (WP6 2017a). For instance, CMS signals that certain criteria could end up in "opening Pandora's box of requalifications," and Ernst and Young discuss the perverse effect of the risk-sharing criterion as revenue authorities could claim that risk is shared and demand their part of the residual profits (WP6 2016a, b). Similarly, the Silicon Valley Tax Directors Group worries about revenue authorities bundling transactions to end up with the right amount of integration to apply the TPSM (WP6 2016b), and BIAC notes the enthusiasm of revenue authorities to use the TPSM in case of significant profits (WP6 2017a). In a way, the tax advisors and industry representatives try to skew the interpretation of the central principle of taxation in their interest to freely plan where to file the residual profits.

Clearly, the declining ideational power of the ALP, or the resistance against the ALP as one of the upheld "truths" in the transfer pricing discourse, threatens TNCs' 
political power to plan their financial and fiscal operations freely. The existence of Global Wealth Chains (GWCs) explains the role of the ALP in maintaining private authority over global tax governance in the form of transfer pricing (Seabrooke and Wigan 2014). Seabrooke and Wigan (2014, p. 257) conceptualize GWCs as the wealth chains that "hide, obscure and relocate wealth to the extent that they break loose from the location of value creation and heighten inequality." Tax planning structures wherein TNCs plan the location of their residual profits to minimize taxation are an example of such a GWC. The ALP then plays a crucial role in preventing regulatory interference as it essentially does not acknowledge the existence of residual profits (Greil 2017). Ylonen and Teivainen (2018, p. 445) describe the role of the ALP herein as the principle that offers a basis for assuming the existence of markets in non-market circumstances. Yet, the TPSM challenges the assumption of market circumstances and in way recognizes that "transacting within an MNC as opposed to on the market suggests MNC formation provides benefits for the firm, which cannot readily be market sourced" (Bryan et al. 2017, p. 75). As a result, the private sector loses some discretion in managing where these profits touch down and become part of a jurisdiction's tax base (Biggins in Bryan et al. 2016, p. 949).

The opening up of the discourse around interpretation of the ALP signals the changing power relations within the expert networks in which the tax advisory industry for long had the upper hand (Buttner and Thiemann 2017; Picciotto 2018a). Although this study misses information on internal WP6 meetings, the sharp dismissal of the private sector's interpretation of the ALP by the US representative sharp dismissal by the US representative of the private sectors indicates that some state representatives and policy-makers no longer fully accept this interpretation as a "truth" within the transfer pricing discourse (WP6 2017a). The USA representative claimed that he basically "tunes out" when he hears the argument that the TPSM only should be used in circumstances where non-related parties would use this method to price their transactions. To some extent, the more skeptical position of WP6 towards the expert network's interpretation signals the politicization of transfer pricing and the decreasing power of the tax advisory industry to set the limits of the transfer pricing discourse.

In addition, the BEPS Monitoring Group actively challenges the private sector consensus (see Fig. 1.3). For instance, the Group's representative, Sol Picciotto, combines expert-based and moral authority to challenge the ALP as he underlines that several of their group members worked in the tax advisory sector but that these members only now, after leaving the industry, are at liberty to denounce the ALP "for obvious reasons" (WP6 2016a). Prof. Picciotto refers to the interests of the tax advisory industry to maintain inefficient concepts as these concepts are essential for the industry to advise TNCs on how to maximize their creative compliance within a complex regulatory framework (Shah 2017; Sharman 2010). Lately, certain civil society organizations became effective in challenging the technocratic consensus in international taxation through their use of different "languages" to politicize tax justice issues (Dallyn 2017). This way, alternative discourses entered insulated policy settings and created uncertainty around the previously upheld "regimes of 
truth." Nonetheless, these civil society advocates needed to combine expertise-based and moral authority to make sure that their claims actually became part of the policy discourse (Seabrooke and Wigan 2016). That said, one thing is clear. The discursive struggles of the private industry on the ALP illustrate that the veneer of market behavior around intra-group planning activities is under threat. Thereby, the discourse of non-interference in market circumstances might not for long ring-fence tax planning behavior from public regulation.

\subsection{The Slicing of the Cake}

A bigger cake brings benefits to all when the slices are shared equally among all participants. While the growing recognition of residual profits in international taxation is a crucial step to retrieve the untaxed profits in tax havens, it is the tax model in combination with the worldwide distribution of foreign direct investment (FDI) that determine whether lower-income countries benefit from these recaptured profits (Cobham et al. 2019). Within a unitary tax regime, the residual profits are part of the cake that is distributed; however, this is not the case under a transactional method within the confines of the separate entity principle as we explained above. The TSPM does not bundle the related party interactions between two or more parties but rather divides the profits related to a specific transaction among the concerned parties. Therefore, developing countries need to make the "right" contributions in their FDI sectors to be part of these "concerned parties" and actually get access to the table where the cake is shared. In this vein, the criteria that justify the application of the TPSM under the most appropriate framework determine the share of the residual profits that potentially strengthens the tax base of lower-income countries. These countries then have a clear material interest to make sure their value chain contributions fall under the criteria that justify the application of the TPSM under the most appropriate framework.

But in Foucault's terms, power shaped the categories, institutions, and discourses of the transfer pricing practice (Kelly 2009). Similar to the historical power relations that formed the source-resident distinction in international taxation, the transfer pricing regime implicitly applies a hierarchy between different value chain contributions. One powerful distinction within the transfer pricing discourse is the difference between "routine," "simple," or "replicable" contributions and "non-routine" functions that create rents or profits above the regular return on capital (Cobham et al. 2019, p. 9). The use of this distinction within the TPSM guidance risks strengthening the power of advanced economies over developing economies in international taxation, especially now that the source-resident debate gains momentum in the Action 1 agenda (Grondona 2019).

Throughout the standard-setting process, WP6 decided that the lack of comparable transactions or CUPs is not a sufficient condition to apply the TPSM, a powerful decision with implications for lower-income countries as these are the ones that struggle the most with the lack of available comparables. This decision is that 
responds to concerns on the use of the TPSM "in the absence of reliable comparables, without considering whether the profit split method was itself appropriate" (OECD/G20 2015, p. 58). In reality, the concern was that TPSM would be applied for "simple functions," and within the transfer pricing discourse, this was seen as "inappropriate" (OECD 2018, p. 14).

de Graaf et al. (2014) already noted the uneven distribution of residual profits between headquarter and basic value chain functions. This exclusion of simple functions for the application of the TPSM adds to this discrepancy and strengthens the imbalance in taxing rights, the right to tax residual profits, between developing countries and advanced economies. Developing countries are still mostly integrated in the initial parts of value chains, by providing primary resources or performing basic manufacturing goods. WP6's exclusion of simple functions thereby creates the situation wherein tax jurisdictions that primarily make "simple" contributions to integrated value chains only receive a marginal share of the overall synergy profits. This way, the allocation of value along the global value chain in the current global tax regime reproduces the uneven patterns of economic development in the world economy, and for this reason others criticized the G20-OECD for its lack of a transparent and inclusive theory on value creation (Quentin and Campling 2018; Wolfram 2019).

The TPSM guidance speaks of an appropriate application when parties share economically significant risks and make unique and valuable contributions to the transaction (OECD 2018). Despite the fact that these contributions are indeed difficult to value under CUP-based methods, the project hereby allocates the weight of synergy profits to the higher or headquarter functions of the TNC. What does this then mean for the project's credo "realign profits with value creation"? Basically, the TPSM guidance neglects a horizontal interpretation of value creation within the GVC wherein "the starting point is the horizontal progression of the GVC from raw materials to the point of consumption, with 'value added' arising at each node along the chain" (Quentin and Campling 2018, p. 47).

From this more horizontal perspective on value creation, captive distributors ${ }^{3}$ also add value that legitimizes a share of the residual profits. Nonetheless, when we listen to the discourse of certain stakeholders on captive distributors, it is clear that these experts underwrite a different interpretation of value, one that diminishes the contribution of the primary nodes in the value chain. The discussion on captive distributors spiraled out of the debate on the presumption of synergy profits in integrated global value chains. Here, CMS questioned the assumption that captive distributors bring in contributions to the global value chain that result in the creation of residual profits, since the contributions of these dependent distributors are similar to unrelated parties (WP6 2017b). In response, the BEPS Monitoring Group pointed

\footnotetext{
3“"Captive value chains. In these networks, small suppliers are transactionally dependent on much larger buyers. Suppliers face significant switching costs and are, therefore, 'captive'. Such networks are frequently characterized by a high degree of monitoring and control by lead firms" (Gereffi et al. 2005, p. 84).
} 
out that captive distributors do bring in additional profits through integration as their relationship is different from unrelated parties in terms of preferential access (WP6 2017b). The US Council for International Business went further and stated that "even if these profits exist, they should be allocated where the strategic decisions responsible for the integration are made" (WP6 2017b). From this perspective, the headquarter functions harvest all the benefits from integration, and the international tax system further re-embeds its bias toward resident-based taxation.

Precisely for this reason, Quentin and Campling (2018) argue that the current interpretation of value creation aligns with a logic of money creation, or value added, instead of a horizontal interpretation of value creation. To illustrate, the reasoning of the US Council follows the pattern of price setting wherein the headquarter would get the residual profits as a result of the relations of control and risk. Conversely, Quentin and Campling (2018) suggest that the current regime lacks a theory on value creation beyond price determined money flows. For this reason, "tax reforms intended to ameliorate global inequalities 'must refocus' to elsewhere in the value chain where the value captured by 'lead firms' is actually created" (Quentin and Campling 2018, p. 52).

Similar to Ylonen and Teivainen (2018), these authors cast a critical light on the role of the ALP and business power in taxation. However, instead of a public-versusprivate logic, Quentin and Campling (2018) bring in a geopolitical dynamic in international taxation. In brief, the authors make a distinction between a vertical and a horizontal logic of value creation wherein the vertical logic follows the pattern of exchange values from the perspective of asset owners. The ALP then suggests that "exchange values between unconnected parties accurately reflect value creation" and thereby excludes a horizontal interpretation of value creation wherein "the starting point is the horizontal progression of the GVC from raw materials to the point of consumption, with 'value added' arising at each node along the chain" (Quentin and Campling 2018, p. 47).

Consequently, the focus on exchange values as a basis for splitting up the profits reproduces the global pattern of extracting surplus value through chains of capital ownership. Therefore, Quentin and Campling (2018) conclude that an international tax regime without a horizontal theory on value creation reproduces global inequalities. In turn, the TPSM guidance judgment on the "inappropriateness" of compensating "simple functions" for synergy profits in fact relates to the inappropriateness of this allocation within a vertical logic of value creation. In contrast to a more horizontal interpretation, a vertical interpretation relates to the actual relations of market power and control in global value chains wherein the dependent producer would not have sufficient bargaining power to share in the residual profits.

Throughout the discussions, the BEPS Monitoring Group brought in the statement that every related party transaction that takes place within a TNC adds to the creation of residual profits as the existence of these profits is the 'raison d'être' of integration in the first place (WP6 2016b, 2017a). Yet, they do not contest the criteria that justify the TPSM as the most appropriate method on the basis of their geopolitical bias, nor push for a more horizontal interpretation of value creation. In general, proposals designed to strengthen tax auditors in BEPS-related challenges fail to 
recognize their geographical redistributive impact (Cobham et al. 2019). For instance, destination-based taxation wins popularity because of its ability to curb tax planning as consumers are less mobile than capital (Auerbach et al. 2017). Nonetheless, these proposals push the benefits of value creation, in terms of taxation, further away from the initial nodes of GVCs, where, for instance, the necessary natural resources are extracted. Cobham et al. (2019) actually simulated the distributive impact of different tax reform packages with the use of data on the global distribution of profits made by American-owned TNCs in the year 2016. Different reform packages, from the OECD, IMF, and the Independent Commission for the Reform of International Corporate Taxation (ICRICT), investigate the option of relocating profits out of tax havens by allocating part of the taxing rights, and especially in terms of residual profits, to market jurisdictions, there where the sales take place. Despite the fact that the location of sales are less vulnerable to manipulation, and therefore an effective route to shift profits out of tax havens, the sole focus on market jurisdictions would be detrimental for lower-income countries (see Table 1.1). First of all, the simulation of Cobham et al. (2019) highlights that the absolute gains of the OECD reform package would bring the least amount of absolute gain to lower-income countries, and the global formulary apportionment (GFA) reforms proposed by ICRICT the most. Importantly, the ICRICT reform does not rely on the strict application of the ALP to calculate the routine profits. But secondly, notwithstanding the potential of these reforms to redirect residual profits out of tax havens, Table 1.1 indicates that sole use of sales as a criterion for the allocation of residual, or surplus profits, favors high-income countries. To highlight the geopolitical dimension of this criterion, Cobham et al. (2019) contrasted these results with the absolute gains of models that use both sales and employment as criteria for profit allocation. Not surprisingly, and especially not when we take in mind the arguments in favor of a more horizontal logic of value creation, these models would bring higher absolute gains to lower-income countries and a more even distribution of the profits in general (see Table 1.1).

At the moment, contestation of the logics of value creation in transfer pricing is still limited (Cobham et al. 2019; Quentin and Campling 2018; Wolfram 2019), and discourses within policy circles regularly reproduce the vertical interpretation of value creation without contention. Here, the unbalanced presence of stakeholders during these stakeholder discussions sets the range of discourses and restricts perspectives from the global south and civil society. For instance, the business representatives that took part in the debate represented the capital owners of TNCs and their headquarter interests. Some of the business representatives seemed especially vocal in the protection of residual profit allocation towards the end of the global value chain and openly protected this distribution during the discussions. For instance, IAPT stated that WP6 needs to be really clear in who takes part in sharing these profits as it does not make sense to give a part of these profits to "some routine manufacturer" (WP6 2017a). On the other, the distinctions between simple and non-routine functions, routine profits, and residual profits are produced through power relations but also part of the knowledge upheld in the discourses on international tax. 


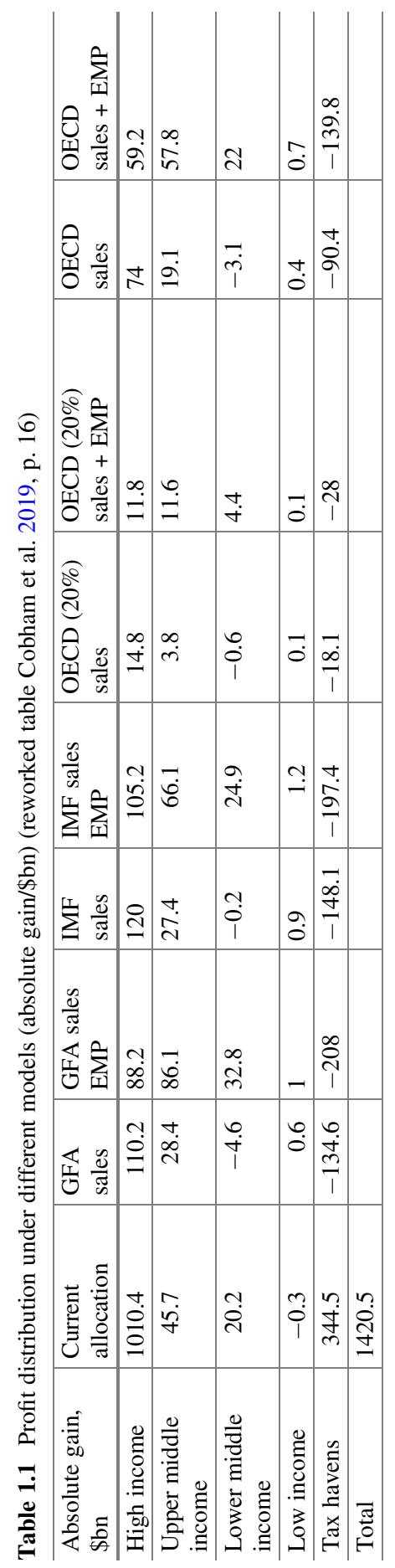


Despite WP6 implicit consensus, Hearson and Prichard (2018) and Picciotto (2018b) illustrate that certain emerging economies have sufficient political cloud to challenge the status quo in international taxation and in the logics on value creation. Specifically, a handful of emerging economies have taken unilateral action and pursue their own interests in transfer pricing. China's, and to some extent India's, practice of using location-specific advantages to decide on how to share the residual profits reeks of a horizontal interpretation of value creation. Basically, the logic of location-based advantages supports the idea that the contribution tax jurisdiction in terms of access to infrastructure, resources, and cheap labor should also be rewarded when splitting up the tax base (Hearson and Prichard 2018).

\subsection{Capturing the Slice and Eating It}

Until now, this discussion focused on the distributional impact of the material rules. However, Van de Vijver et al. (2020) revealed the shortcomings of the BEPS reforms in fostering responsible tax behavior of TNCs. Therefore, countries rely on transfer pricing audits to requalify the reported profits and claim their "rightful" share of the cake. The difficult shift from aggressive tax planning to more responsible tax behavior is even more problematic for lower-income countries as transfer pricing audits are complicated and costly procedures. As a result, the TPSM guidance could also readdress the distribution of the global tax base in favor of lowerincome countries by simplifying the regime (Picciotto 2018b; Greil 2017; Mehta and Siu 2016). At first, the policy reform of the TPSM was applauded for its potential to simplify the regime (Mehta and Siu 2016; Greil 2017). However to this date, the current outcomes do not contain any steps toward standardization in terms of sectoral approaches or in terms of profit splitting factors, and the initial enthusiasm of these scholars faded way (Kadet et al. 2018).

Whereas the BEPS Monitoring Group argued for standardization throughout the discussion, the private sector representatives, and in particular the tax advisory sector, stipulated the non-prescriptive character of the TPSM guidance. These advisors defended the "correct sequence" in transfer pricing, wherein the decision on both the most appropriate method and the choice of the profit splitting factors follows the accurate delineation of the transaction (WP6 2016b, 2017a). This is in the interest of the tax advisory sector as the complexity and length of transfer pricing procedures are fundamental to part of their profit-making activities (Sikka and Hampton 2005). In the end, the advisory sector's discourse was at winning end of this struggle, and the final guidance explicitly stated its non-prescriptive character (OECD 2018).

Essentially, the primacy of the accurate delineation of the transaction underlines the case-by-case logic in the TPSM guidance. This accurate delineation of the transaction comes down to an in-depth analysis of the transaction through the functions, risks, and assets involved. By adhering to this case-by-case approach in transfer pricing, the G20-OECD project maintains an information and a capacity bias 
against the interests of developing countries (Kadet et al. 2018). First of all, the selection of the most appropriate method builds on this analysis. Inevitably, TNCs have access to more in-depth information on their operations than any revenue authority, and revenue authorities therefore have to play a game of catch-up while auditing the adequacy of TNCs' functional analysis that underpins the method and the transfer price.

Secondly, revenue authorities are in need of very specialized and complex expertise to perform this analysis and revenue authorities in the global south struggle to build this capacity, TNCs employ tax advisors part of transnational expert community focused on transfer pricing (Kadet et al. 2018). The tax advisory industry is invested in keeping the case-by-case logic in place as this approach maintains the complexity and discretion in the application of the regime (Picciotto 2018a), a complexity needed to continue the profitable business of advising on tax planning strategies and strategic compliance (Shah 2017; Sikka and Hampton 2005). On the other, the advisory industry protects its almost epistemic and existential position in transfer pricing, as both business and regulators need these experts to make the current regime work. Accordingly, it is no surprise that the industry was most active in preserving the case-by-case logic in transfer pricing and dominated most of this overall debate (see Fig. 1.3).

Similar to the tug-of-war over the size of the cake, the struggles over standardization inhabit a public-versus-private authority logic, but, in contrast to the discussion on the existence of residual profits, private interests prevail this time around. In part, the difference in capacity bias between low- and high-income countries explains the weakness of the standardization plight as revenue authorities within advanced economies are well resourced with tax auditors part of the transnational network of transfer pricing experts (BEPS Monitoring Group 2018).

Finally, Ylonen and Teivainen (2018)'s thesis on the role of the ALP clarifies the importance of the ALP discourse to prevent standardization as this discourse supports the idea of market relations in non-market circumstances. In fact, the ALP slows down the demand for regulatory intervention through standardization, as it supports the ideology of non-intervention in intra-company planning. One tax advisor's statement captures this discourse perfectly, as he stated that "the guidance should not interfere with the TNC's ability to independently decide on its capital structure" (WP6 2017a). In a way, this discourse, in favor of a case-by-case logic, supports the idea that public authorities are not supposed to decide how these prices should be set or mediated within a capital chain of a TNC. Instead, price setting should follow "the market," and TNCs should have the prerogative to structure its capital as they see fit. 


\subsection{Conclusions}

Mosquera Valderrama et al. (2018) pointed out that the BEPS Inclusive Framework, designed to expand the reach of the G20-OECD BEPS project, emphasizes integration through implementation but neglects integrating these countries in the negotiation of these standards. That said, in this chapter we argued through our analysis of power relations during the TPSM process that the underrepresentation of the material interests of lower-income countries cannot be solely addressed by giving these countries a seat at the table. After a critical look of dynamics at play, we conclude that the pure participation of developing countries in the standard-setting forums is not sufficient to guarantee output legitimacy for these countries. The discourses and "truths" upheld in the negotatiated outcomes maintain a distributive imbalance between low- and high-income countries and hand out higher rewards to jurisdictions that host the higher value chain functions of the global value chain. Specifically, discourses built on the arm's length principle and a vertical interpretation of value creation work in favor of this status quo.

Throughout our discussion, the uneven distribution of residual profits was our topic of interest as developing countries are generally excluded from participating in these profits. Therefore, we added another layer to Mosquera Valderrama (2018)'s discussion on output legitimacy, namely, distributive justice. Distributive justice requires collective action as developing countries cannot solve the lack of distributive justice in the current status quo "through individual action, through market exchanges, or through voluntary cooperation in civil society" (Scharpf in Mosquera Valderrama 2015). In the case of the revised TPSM guidance, the distributional outcome of the BEPS process undermines the output legitimacy of the regime for lower-income countries. Specifically, the guidance only reshuffles the authority on the allocation of residual profits from private to public authority but neglects to integrate criteria that take into account the contributions from lower-income countries and fails to take steps toward a more implementable regime. As a result, the standard-setters decided on a bigger cake, but lower-income countries only got the crumbs of this cake without the tools to actually eat it.

This observation raises some questions on the demand for transfer pricing assistance and the rollout of capacity building projects wherein these guidelines are a point of reference in terms of "appropriate" transfer pricing governance. Hereby we shed a critical light on the distributional consequences of the capacitybased approach toward the integration of lower-income developing countries. The problem of administrability of the TPSM in lower-income countries clearly captures the different modalities of integrating developing countries within the international tax regime. On one hand, the regime acknowledges the problem of a capacity bias against lower-income countries and invests in technical assistance and capacity building. In turn, the strengthened expertise and capacity within tax administrations should make lower-income countries more likely to effectively participate in the current regime (Mosquera Valderrama et al. 2018). On the other hand, lower-income countries are expected to take a seat at the table and take part in the transfer pricing 
discourse without the acknowledgement or an open discussion on the distributional bias of this knowledge.

Yet, the current framework is not set in stone as the continuous discussion on taxing rights in the work on the digitalized economy illustrates. Maybe the revised guidance of the TPSM did not bring solace for developing countries, but it did reveal that order in international taxation is shifting. In other words there is a momentum to commit and make sure that the lower-income countries will not yet again end up with the short end of the stick.

\section{References}

Auerbach, A. J., Devereux, M. P., Keen, M., \& Vella, J. (2017). International tax planning under the destination-based cash flow tax. National Tax Journal, 70, 783-801.

BEPS Monitoring Group. (2018). Submission to the subcommittee on article 9 (associated enterprises) on the revision of the UN practical manual on transfer pricing for developing countries. United Nations Committee of Experts on International Cooperation in Tax Matters.

Bryan, D., Rafferty, M., \& Wigan, D. (2016). Politics, time and space in the era of shadow banking. Review of International Political Economy, 23(6), 941-966. https://doi.org/10.1080/09692290. 2016.1139618.

Bryan, D., Rafferty, M., \& Wigan, D. (2017). Capital unchained: Finance, intangible assets and the double life of capital in the offshore world. Review of International Political Economy, 24(1), 56-86. https://doi.org/10.1080/09692290.2016.1262446.

Buettner, T., \& Thiemann, M. (2017). Breaking regime stability? The politicization of expertise in the OECD/G20 process on BEPS and the potential transformation of international taxation. Accounting Economics and Law-a Convivium, 7(1). https://doi.org/10.1515/ael-2016-0069.

Burgers, I., \& Mosquera Valderrama, I. J. (2017). A fair slice for developing countries. Erasmus Law Review, 10(29), 767-783.

Christensen, R. C. (2020). Transparency. In L. Seabrooke \& D. Wigan (Eds.), Global wealth chains: Asset strategies in the world economy. Oxford: Oxford University Press.

Christensen, R. C., \& Hearson, M. (2019). The new politics of global tax governance: Taking stock a decade after the financial crisis. Review of International Political Economy, 26(5), 1068-1088. https://doi.org/10.1080/09692290.2019.1625802.

Christians, A. (2017). BEPS and the new international tax order. Brigham Young University Law Review, 2016(6), 1603-1647.

Cobham, A., Faccio, T., \& FitzGerald, V. (2019). Global inequalities in taxing rights: An early evaluation of the OECD tax reform proposals. SocArXiv. https://doi.org/10.31235/osf.io/j3p48

Dallyn, S. (2017). An examination of the political salience of corporate tax avoidance: A case study of the tax justice network. Accounting Forum, 41(4), 336-352. https://doi.org/10.1016/j.accfor. 2016.12.002.

de Graaf, A., de Haan, P., \& de Wilde, M. (2014). Fundamental change in countries' corporate tax framework needed to properly address BEPS. Intertax: International Tax Review, 42(5), 306-316.

Fuest, C., \& Riedel, L. (2012). Tax evasion and tax avoidance: The role of international profit shifting. In P. Reuters (Ed.), Draining development (pp. 109-142). Washington, DC: World Bank.

Gereffi, G., Humphrey, J., \& Sturgeon, T. (2005). The governance of global value chains. Review of International Political Economy, 12(1), 78. https://doi.org/10.1080/09692290500049805.

Greil, S. (2017). The dealing at arm's length fallacy: A way forward to a formula-based transactional profit split? Intertax: International Tax Review, 45(10), 624-630. 
Grinberg, I. (2016). The new international tax diplomacy. Georgetown Law Journal, 104(5), 1137-1196.

Grondona, V. (2019). The dangers if the residual profit split. Retrieved from https://www. taxjustice.net/2019/10/03/the-dangers-of-the-residual-profit-split/

Hearson, M. (2018a). The challenges for developing countries in international tax justice. Journal of Development Studies, 54(10), 1932-1938. https://doi.org/10.1080/00220388.2017.1309040.

Hearson, M. (2018b). When do developing countries negotiate away their corporate tax base? Journal of International Development, 30(2), 233-255. https://doi.org/10.1002/jid.3351.

Hearson, M., \& Prichard, W. (2018). China's challenge to international tax rules and the implications for global economic governance. International Affairs, 94(6), 1287-1307. https://doi.org/ 10.1093/ia/iiy 189.

Kadet, J. M., Faccio, T., \& Picciotto, S. (2018). Profit-split method: Time for countries to apply a standardised approach. Institute of Development Studies, International Centre for Tax and Development.

Kelly, M. G. E. (2009). The political philosophy of Michel Foucault. Routledge studies in social and political thought (Vol. 61, 1st ed.). New York: Routledge.

Kelly, M. G. E. (2014). Foucault and politics: A critical introduction. Thinking politics. Edinburgh: Edinburgh University Press.

Lesage, D., \& Vermeiren, M. (2011). Neo-liberalism at a time of crisis: The case of taxation. European Review, 19(1), 43-56. https://doi.org/10.1017/S1062798710000372.

Lips, W. (2019). Great powers in global tax governance: A comparison of the US role in the CRS and BEPS. Globalizations, 16(1), 104-119.

Lukes, S. (2005). Power: A radical view (2nd ed.). Basingstoke: Palgrave Macmillan.

Magelhaes, T. D. (2018). What is really wrong with global tax governance and how to properly fix it. World Tax Journal, 10(4), 499-536.

Mehta, K., \& Siu, E. D. (2016). Ten ways developing countries can take control of their own tax destinies. In T. Pogge \& K. Mehta (Eds.), Global tax fairness (pp. 339-356). Oxford: Oxford University Press.

Mosquera Valderrama, I. J. (2015). Legitimacy and the making of international tax law: The challenges of multilateralism. World Tax Journal, 7(3), 344-366.

Mosquera Valderrama, I. J. (2018). Output legitimacy deficits and the inclusive framework of the OECD/G20 base erosion and profit shifting initiative. Bulletin for International Taxation, 73(3), 1-11.

Mosquera Valderrama, I. J., Lesage, D., \& Lips, W. (2018). Tax and development: The link between international taxation, the base erosion profit shifting project and the 2030 sustainable development agenda. UNI-CRIS Working Paper Series. UNU-CRIS.

OECD. (2015). Addressing the tax challenges of the digital economy, action 1. 2015 final report. OECD/G20 base erosion and profit shifting Project. Paris: OECD.

OECD. (2017a). Background brief inclusive framework on BEPS. Paris: OECD. Retrieved from https://www.oecd.org/tax/beps/background-brief-inclusive-framework-for-beps-implementa tion.pdf

OECD. (2017b). Public discussion draft BEPS action 10 revised guidance on profit splits. Paris: OECD. Retrieved from https://www.oecd.org/tax/transfer-pricing/Revised-guidance-on-profitsplits-2017.pdf

OECD. (2018). Revised guidance on the application of the transactional profit split method: Inclusive framework on BEPS: Action 10. Paris: OECD. Retrieved from www.oecd.org/tax/ beps/revised-guidance-on-the-application-of-the-transactional-profit-split-method-beps-action10.pdf

OECD. (2019). Programme of work to develop a consensus solution to the tax challenges arising from the digitalisation of the economy. OECD/G20 Inclusive Framework on BEPS. Paris: OECD. Retrieved from www.oecd.org/tax/beps/programme-of-work-to-develop-aconsensussolution-to-the-tax-challenges-arising-from-the-digitalisation-of-the-economy.htm 
OECD/G20. (2015). BEPS project: Aligning transfer pricing values with value creation-Actions $8-10$. Final reports. Paris: OECD.

Peters, C. (2015). Developing countries' reactions to the G20/OECD action plan on base erosion and profit shifting. Journal International Taxation, 69(6/7), 1-11.

Picciotto, S. (1992). International taxation and intrafirm pricing in transnational corporate groups. Accounting Organizations and Society, 17(8), 759-792. https://doi.org/10.1016/0361-3682(92) 90003-B.

Picciotto, S. (2015). Indeterminacy, complexity, technocracy and the reform of international corporate taxation. Social and Legal Studies, 24(2), 165-184. https://doi.org/10.1177/ 0964663915572942.

Picciotto, S. (2018a). International tax, regulatory arbitrage and the growth of transnational corporations. Institute of Development Studies, International Centre for Tax and Development.

Picciotto, S. (2018b). Problems of transfer pricing and possibilities for simplification. ICTD working paper 86:61.

Quentin, D., \& Campling, L. (2018). Global inequality chains: Integrating mechanisms of value distribution into analyses of global production. Global Networks-A Journal of Transnational Affairs, 18, 33-56. https://doi.org/10.1111/glob.12172.

Seabrooke, L., \& Wigan, D. (2014). Global wealth chains in the international political economy. Review of International Political Economy, 21(1), 257-263. https://doi.org/10.1080/09692290. 2013.872691.

Seabrooke, L., \& Wigan, D. (2016). Powering ideas through expertise: Professionals in global tax battles. Journal of European Public Policy, 23(3), 357-374. https://doi.org/10.1080/13501763. 2015.1115536.

Shah, A. K. (2017). The politics of financial risk, audit and regulation: A case study of HBOS. Abingdon: Routledge.

Sharman, J. C. (2010). Offshore and the new international political economy. Review of International Political Economy, 17(1), 1-19. https://doi.org/10.1080/09692290802686940.

Sikka, P., \& Hampton, M. P. (2005). The role of accountancy firms in tax avoidance: Some evidence and issues. Accounting Forum, 29(3), 325-343. https://doi.org/10.1016/j.accfor. 2005.03.008.

Tax Inspectors Without Borders. (2018). Annual report 2017/2018 tax inspectors without borders. Retrieved from http://www.tiwb.org/resources/publications/tax-inspectors-without-bordersannual-report-2017-2018-web.pdf

Van de Vijver., A, Cassimon., D, \& Engelen., P.-J. (2020). A real option approach to sustainable corporate tax behavior. Sustainability, 12(13), 5406, 1-17.

Waris, A. (2017). How Kenya has implemented and adjusted to the changes in international transfer pricing regulations: 1920-2016. ICTD working paper 69. Institute of Development Studies, International Centre for Tax and Development.

Wolfram, F. R. (2019). Aligning profit taxation with value creation. Munich: CESifo Group.

WP6, B. (2016a). WP6 public consultation-Revised guidance on profit splits-First session. Paris: OECD.

WP6, B. (2016b). WP6 public consultation-Revised guidance on profit splits-Second session. Paris: OECD.

WP6, B. (2017a). Public consultation: Revised guidance on profit splits—First Session. Paris: OECD.

WP6, B. (2017b). Public consultation: Revised guidance on profit splits—Second Session. Paris: OECD.

Ylonen, M., \& Teivainen, T. (2018). Politics of intra-firm trade: Corporate price planning and the double role of the arm's length principle. New Political Economy, 23(4), 441-457. https://doi. org/10.1080/13563467.2017.1371124. 
Open Access This chapter is licensed under the terms of the Creative Commons Attribution 4.0 International License (http://creativecommons.org/licenses/by/4.0/), which permits use, sharing, adaptation, distribution and reproduction in any medium or format, as long as you give appropriate credit to the original author(s) and the source, provide a link to the Creative Commons license and indicate if changes were made.

The images or other third party material in this chapter are included in the chapter's Creative Commons license, unless indicated otherwise in a credit line to the material. If material is not included in the chapter's Creative Commons license and your intended use is not permitted by statutory regulation or exceeds the permitted use, you will need to obtain permission directly from the copyright holder. 